\title{
Unconfined Groundwater Dispersion Model on Sand Layers in Coral Island
}

\author{
Sultan $^{1}$, Imran, A.M², Thaha, M.Arsyad ${ }^{3}$, Ramli, Muhammad ${ }^{4}$ \\ ${ }^{1}$ Doctoral Student of Civil Engineering, Postgraduate, Hasanuddin University, Makassar 90245, Indonesia \\ ${ }^{2,4}$ Geology Engineering Lecturer, Hasanuddin University, Makassar 90245, Indonesia \\ ${ }^{3}$ Civil Engineering Lecturer, Hasanuddin University, Makassar 90245, Indonesia
}

\begin{abstract}
The research objective is to analyze the sand layer to determine the characteristics of the unconfined groundwater aquifer on coral island and found the dispersion model of unconfined groundwater in the sand layer in the coral island. The method used is direct research in the field, laboratory analysis and secondary data. Observations geological conditions, as well as the measurement and interpretation of geoelectrical potential groundwater models based on the value of the conductivity of groundwater from 20 wells dug and 15 test wells in Satando Island the rainy season, the transition season and the dry season with Groundwater Modelling software. Geological mapping indicates Satando Island area is a coastal plain that is still active with the type of alluvial coast and the elevation of 0,0 to 2,3 meters. Interpretation of geoelectrical cross-section resulted in the composition of soil and rock layers vertically in the central part of the island consists of overburden $(0-0,5 \mathrm{~m})$, fine sand - coarse $(0,5-3,5 \mathrm{~m})$, limestone reefs $(3,5$ - $12 \mathrm{~m})$, fractured limestones $(12-39 \mathrm{~m})$, limestone $(39-57 \mathrm{~m})$ and a solid limestone $(57-78.8 \mathrm{~m})$. Freshwater needs Satando Island residents $32.22 \mathrm{~meter} /{ }^{3} / \mathrm{day}$. Dispersion model unconfined groundwater coral island in the rainy season to produce a layer thickness of fresh water in the central part of the island is 2.74 meters $\left(-1.33 \mathrm{~m}\right.$ below sea level), which produces the potential for fresh water in the sand layer is $10588.2 \mathrm{~m}^{3}$, which can be used only $2117.62 \mathrm{~m}^{3}$ are able to meet the needs of fresh water island residents. As the season transitions freshwater layer thickness in the central part of the island is only 2.10 meters (-0.93 m below sea level), which produces the potential for fresh water in the sand layer is $4688.9 \mathrm{~m}^{3}$, which can be used only $937.78 \mathrm{~m}^{3}$ are still able to meet the fresh water of the island residents but have had to wait 2-3 hours to get fresh water. During the dry season the thickness of the layer of fresh water in the central part of the island is only 1.54 meters $\left(-0.53 \mathrm{~m}\right.$ below sea level), which produces the potential for fresh water in the sand layer is $1375.9 \mathrm{~m}^{3}$, which can be used only $275.18 \mathrm{~m}^{3}$ ( water that is above a depth of 1.75 meters), supply of fresh water on the island is not able to meet all the needs of the residents of the island, so that should bring fresh water from the mainland to meet the needs of fresh water.
\end{abstract}

Keywords: Dispersion model, sand layer, coral island, unconfined groundwater

\section{Introduction}

\subsection{Background}

The genesis of constituent rocks of small islands is varies process. Small islands in Indonesia, based on the genesis can be classified as an island volcanic, tectonic island, delta island and coral island (Adang, 2009). Grouping genesis of this island produces morphology, soil type, resistivity and conduktivity groundwater and unconfined groundwater dispersion models differ from one island to another island, depending on geological conditions and water content in the area of the island. One of the dominant rock types making up for the small islands are coral rock in the form of sand-sized material and limestone reefs. The type of soil and rock that make up the small islands usually different and varied eg arranged by the type of soil sand coral, limestone reefs, volcanic rock, tectonic rocks, delta an alluvial will provide a layer of groundwater potential of different (Arenas, 1991; Benfetta, 2009). The type of soil and rock that varies also produces a variety of different resistivity value (Rolia, 2011).

In the area of small islands generally a coral island composed of sand and limestone reef material, often encountered the problem of shortage of fresh water. This is because the amount of groundwater that is sweet is trapped in the layers aquifer small islands that form coral islands are limited, fewer than from the big island for the model of the aquifer is generally shaped like a lens and coating the surface of the island is relatively well organized by the type of soil on coral and have porosity and permeability of the porous so easily intruded sea water because fresh water specific gravity less than the density of sea water. In addition, the decision process in the atoll groundwater is rapid, especially when done with pumping systems, but recharge groundwater requires a very long time because it naturally has to go through a pore soil and small rocks. Therefore, in the area of small islands needs to be done intensive groundwater conservation and appropriate to maintain the presence of fresh water in the area (Fatimah and Sobriyah, 2006).

Husni (2010), seawater intrusion could occur because of, among others, changes in land use and deforestation of mangroves and the number of residents who use groundwater for the purpose of water supply, resulting in a change of equilibrium hydraulic between pressure fresh water and sea water which causes sea water intrusion into landward. Additionally beach characteristics, soil and rocks making up the island as well as fluctuations in the groundwater in the area is causing contamination of freshwater into brackish to salt. Deterioration in the quality of groundwater can be seen from the level of salinity of groundwater based on the levels of chloride ion indicated by the value of total dissolved solids and electrical conductivity value of groundwater in the area. Kodoatie (2012), the occurrence of seawater intrusion associated with the change process interface. In an area close to the beach or close to the 


\section{International Journal of Science and Research (IJSR) \\ ISSN (Online): 2319-7064}

Index Copernicus Value (2013): 6.14 | Impact Factor (2014): 5.611

sea, there was a meeting between seawater with fresh water that is known as an interface that could juts into the sea and can also inland, depending on the size of rain water recharge. If a very large rainwater recharge, then the interface will be jutting into the sea, while rainwater recharge little or nothing at all, then the interface will jutted into the ground. Changes in soil by augmentation or external changes in the flow of fresh water areas causes changes in the interface.

Water is a basic requirement that is essential for the survival of living beings, so that the availability of surface and ground water is a blessing for mankind. Deployment potential and availability of groundwater relation to the balance of the water balance, particularly on small islands are very dependent on the type of soil and rocks, geological conditions, geohydrology and meteorological conditions in the area. Layer of the aquifer as a layer of carrier groundwater in the area of small islands very limited distribution, so it takes research more detail to find out how to model the dispersion of groundwater in the area of small islands so that they can determine the potential for groundwater in the area of the island, which will be used to determine the shape of the conservation of groundwater in the area of small islands right on regional conditions that are relatively similar (Yudianto, 2006).

\subsection{Objectives and Benefits}

The research objective is to analyze the sand layer to determine the characteristics of the unconfined groundwater aquifer on coral island and found the dispersion model of unconfined groundwater in the sand layer in the coral island. Benefits of the research was to determine the greater the potential for ground water in the rainy season, the transition season and the dry season and increase knowledge of soil water conservation in the coral island.

\section{Literature Riview}

\subsection{Soil, Rocks, Permeability and Aquifer}

Potential groundwater contained on this earth nearly $95 \%$ contained in the sedimentary rock or rock that had rotted and decomposed into the ground, one of which can be found on coral sand layer that generally make up the surface of the coral island. Sedimentary rocks found around $75 \%$ cover the surface of the continents and almost $85 \%$ of these rocks covering the surface of the sea, while igneous representing $95 \%$ of the Earth's crust by volume, but the rock was only $2 \%$ of the entire volume of the earth's crust. Based on the mineral composition of the main constituent of sedimentary detritus (clastic), it can be divided into 3 types (Pettijohn, 1975) :

- Carbonate clastic sedimentary rocks (limestone) or limestone clastic has major mineral composition of calcite $\left(\mathrm{CaCO}_{3}\right)$, carbonate rocks are almost entirely composed of calcium carbonate or specifically the rock containing more than $95 \%$ calcite and dolomite is less than $5 \%$.

- Volcanic clastic sedimentary rocks with the main material of the result of volcanic activity (mineral glass, crystal or mineral lytic).
- Sedimentary silisiclastic rocks, mineral composition of sedimentary rocks is determined by the mineral composition of the rock, rock fragments with its major constituent minerals are quartz and feldspar.

Mineral constituent of sedimentary rocks could be vulnerable or susceptible to the leaching process (dissolution), recrystallization and replacement, various types of rock minerals can be distinguished on the primary and secondary minerals. Primary mineral resistant to weathering such as quartz, zircon, concretions of iron, opaque, while the minerals are easily weathered including the minerals feldspar, ferromagnesian such as olivine, pyroksin, amphibol and volcanic glass, while the fraction of non carbonate include: quartz, feldspar, gypsum, glauconite (Boggs, 1995). Soil classification based on the texture of the USDA (Das, 1995) in which the texture of the soil is influenced by the size of each item that is in the ground, so that its name is based on the main component material contained in the soil in the form of gravel, sand, silt and clay (Fig.1).

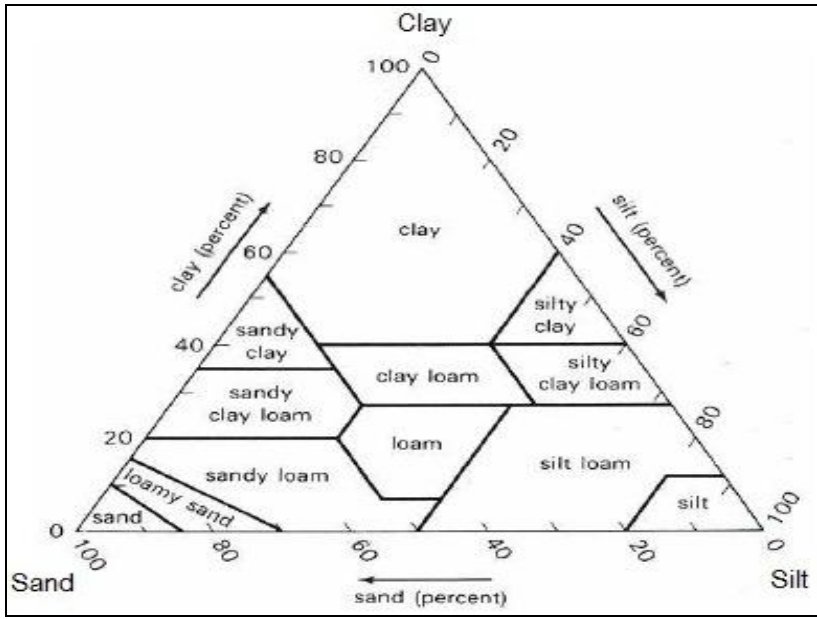

Figure 1: Diagram klasifikasi tanah USDA (Das, 1995)

Hardiyatmo (2001), to determine the appropriate soil permeability coefficient, the laboratory tests must be conducted. There are two ways to determine the coefficient is to test a fixed voltage and test voltage is decreasing. Test voltage is still used mainly for land that has a coarse and high permeabiitas coefficients $\left(>10^{-3} \mathrm{~cm}^{3} / \mathrm{s}\right)$ using the formula :

Discharger $\mathrm{Q}=$ k.i.A.t $=k \cdot \frac{h}{L}$. A.t then $\quad k=\frac{Q \cdot L}{h \cdot A \cdot t} \quad \ldots .$. (1)

$\mathrm{Q}=$ discharge water stored

$\mathrm{h}=$ height of the energy lost

$\mathrm{k}=$ permeability coefficient

$\mathrm{L}=$ length of the object tested

$\mathrm{A}=$ cross-sectional area of the test specimen

Table 1: Soil permeability coefficient (Hardiyatmo, 2001)

\begin{tabular}{|c|c|c|c|}
\hline No & type of soil & $\begin{array}{c}\text { Permeability } \\
\text { coefficien (k) } \\
\text { cm/second }\end{array}$ & Commentary \\
\hline 1 & coarse grains & $10^{2}-10^{-1}$ & high permeability \\
\hline 2 & $\begin{array}{c}\text { Fine gravel / sand is } \\
\text { coarse }\end{array}$ & $10^{-1}-10^{-3}$ & medium permeability \\
\hline 3 & Fine sand, silt sand & $10^{-3}-10^{-5}$ & low permeability \\
\hline
\end{tabular}




\section{International Journal of Science and Research (IJSR) \\ ISSN (Online): 2319-7064}

Index Copernicus Value (2013): 6.14 | Impact Factor (2014): 5.611

\begin{tabular}{|c|c|c|c|}
4 & $\begin{array}{c}\text { Dense silt, silty clay, } \\
\text { Silt impure }\end{array}$ & $10^{-5}-10^{-7}$ & $\begin{array}{c}\text { Very low } \\
\text { permeability }\end{array}$ \\
\hline 5 & Clay & $<10^{-7}$ & Impervious \\
\hline
\end{tabular}

Neyamadpour, etc. 2009 in the study of hydrogeology, the earth's surface consists of four different layers, namely aquiclude, aquitard, aquifuge and aquifer. Kodoatie (2012), aquifer layers classified into five types : confined aquifer, semi-confined aquifer, semi-unconfined aquifer, unconfined aquifer and artesian aquifer.

\subsection{Resistivity Method Geoelectrical}

Resistivity method geoelectrical type is one of geophysical methods that can give you a structure and depth of soil and rock, by measuring the electrical properties of rocks. Survey resistivity geoelectrical mapping and sounding methods generate information changes variations in resistivity both laterally and vertically in an area. Each of the different rock will have a price of resistivity are different, it depends on several factors, such as age of rocks, electrolyte content, rock density, the amount of minerals it contains, porosity and permeability (Cindhy, et al., 2012). In addition geoelectrical measurements such as Fig.2.

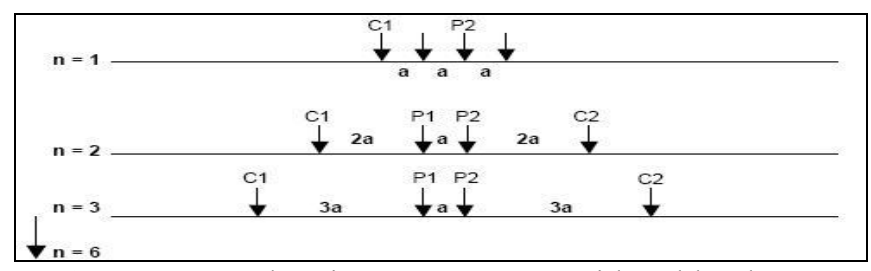

Figure 2: Geoelectric measurements with Schlumberger configuration (Telford, 1990)

Geoelectrical sounding measurement method using Wenner Schlumberger electrode arrangement methods, methods of mapping using electrode array wear Wenner-Schlumberger combined potential $\mathrm{MN}$ and current $\mathrm{AB}$ (Sultan, 2008). Measurement of geoelectric resistivity sounding method and Schlumberger electrode arrangement must qualify MN/2 do not exceed the maximum distance $1 / 5$ of $A B / 2$. Stretch of electrode currents change every measurement, then the price of the apparent resistivity obtained from the formula (Akos, 2010) as follows: $\Omega=K . \frac{V}{I}$

$K=\frac{\pi}{4 a} \cdot\left(L^{2}-a^{2}\right)$

$\Omega=$ apparent resistivity $(\mathrm{Ohm}$ metre $)$

$\mathrm{V}=$ potential difference (mVolt)

$\mathrm{I}=$ current difference is used (m Ampere)

$\pi=$ phi correction value of 3,14

$\mathrm{a}=$ distance expanse $\mathrm{MN}$ (metres)

$\mathrm{K}=$ coefficient of geometrical

$\mathrm{L}=$ distance expanse $\mathrm{AB}$ (metres)

Resitivity value of each type of soil/rock can be distinguished as shown Vingoe, 1972 in Telford., Et al., 1990 (Table 2).

Table 2: Resistivity value of soil and rock types (Vingoe, 1972 in Telford, 1990)

\begin{tabular}{|c|c|c|c|}
\hline Type of Soils & $\begin{array}{c}\text { Resistivity } \\
(\text { Ohm.m) }\end{array}$ & Type of Rocks & $\begin{array}{c}\text { Resistivity } \\
(\text { Ohm.m) }\end{array}$ \\
\hline Clay / marl & $1-10^{3}$ & Sandy pebbles & $10-10^{4}$ \\
\hline Clayed & $10-10^{2}$ & Coralstone & $10-10^{3}$ \\
\hline
\end{tabular}

\begin{tabular}{|c|c|c|c|} 
Clay soil & $10^{2}-10^{4}$ & Limestone & $10^{2}-10^{5}$ \\
\hline Sandy soil & $10^{2}-10^{3}$ & Sandstone & $10^{2}-10^{6}$ \\
\hline Loose soil & $10^{2}-10^{5}$ & Crystalline rock & $10^{3}-10^{7}$ \\
\hline
\end{tabular}

Modeling layers of soil and rock that contained a coral island be done by making a cross-2D based on the value of resistivity using software Res2dinv (Zbigniew, et al, 2011).

\subsection{Groundwater Conductivity Value}

Value conductivity is a measure of how strongly the value of a solution (groundwater) can conduct electricity which is the opposite of the electrical resistance or resistivity value (Priscilla, 2008; Khodapanah, 2009): $\quad \mathrm{R}=\rho \mathrm{L} / \mathrm{A}$.......... ( 3)

$\mathrm{R}=$ the electrical resistance expressed in ohms $(\Omega)$

$\rho=$ the specific prisoners or the resistivity in ohm.m (SI units)

$1=$ the length in meters A cross-sectional area in $\mathrm{m}^{2}$

The ability of a material (G) to conduct electrical current (electrical conductivity) is inversely proportional to the electrical resistance (R), has a unit of ohms $\left(\mathrm{ohm}^{-1}\right)$ or Siemens (S). When electric current is applied to a solution via two electrodes, the electrical conductivity of the solution is proportional to the broad field electrode (A) and inversely proportional to the distance between the two electrodes (l) : $\mathrm{G}=1 / \mathrm{R}=\mathrm{K} \cdot \mathrm{A} / \mathrm{l}$

(4)

$\mathrm{K}=$ the conductivity $\left(\mathrm{ohm} \mathrm{m} \mathrm{m}^{-1}\right.$ or Sm$\left.^{-1}\right) . \mathrm{A} / \mathrm{l}=\mathrm{a}$ constant cell $\mathrm{G}=$ the electrical conductivity $\left(\mathrm{ohm}^{-1}\right)$, Telford, et al., 1990

The conductivity of water depends on the amount of dissolved ions in the liquid/volume and mobility of the ions in the liquid. The unit is $\left(\mu \mathrm{mh}^{\circ} / \mathrm{cm}, 25^{\circ} \mathrm{C}\right)$. Conductivity increases by the same amount with increasing salinity.

Table 3: Classification of water based on conductivity (Davis, 1996 in Cole Parmer, 2006)

\begin{tabular}{|c|c|c|}
\hline No & $\begin{array}{c}\text { Electrical Conductivity (Conductivity) } \\
\left(\mu \mathrm{mh}^{\circ} / \mathrm{cm}, 25^{\circ} \mathrm{C}\right)\end{array}$ & Water Clasifications \\
\hline 1 & 0,0055 & Pure water \\
\hline 2 & $0,5-5$ & Distilled water \\
\hline 3 & $5-30$ & Rainwater \\
\hline 4 & $30-200$ & Groundwater \\
\hline 5 & $200-500$ & Brackish water \\
\hline 6 & $500-55.000$ & Sea water \\
\hline
\end{tabular}

\subsection{Groundwater Dispersion Zone}

Dispersion zone is a zone where a substance is uniformly dispersed (dispersed phase) in another substance (phase dispersing or medium). The dispersed phase is discontinuous (intermittent) while the dispersion medium is continuous. Katsifarakis (2009), generally in a medium there are 3 types of dispersion zones : solutions, suspensions and colloids.

Dispersion zone models of groundwater in area of the island is still based on a zone dispersion in coastal regions are based on the principle Ghyben - Herzberg (Kodoatie, 2012), which is still considering the conditions of density fresh water, density of sea water, the water level freshwater and depth interface in the area, formula:

\section{Volume 5 Issue 7, July 2016




\section{International Journal of Science and Research (IJSR) \\ ISSN (Online): 2319-7064}

Index Copernicus Value (2013): 6.14 | Impact Factor (2014): 5.611

$$
h s=\frac{\rho f}{\rho s-\rho f} . h f
$$

$\rho f=$ the density of freshwater $\quad \rho s=$ the density of sea water $\mathrm{hf}=$ the fresh water level depth $\quad \mathrm{hs}=$ depth interface

When the flow through the layers at a price of $\mathrm{K}$ different, then the flow lines will be refracted according the formula:

$$
\frac{\tan \theta 1}{\tan \theta 2}=\frac{K 1}{K 2}
$$

$\theta 1, \theta 2, \theta 3=$ angle of refraction at layer $1,2,3$

$\mathrm{K} 1, \mathrm{~K} 2, \mathrm{~K}=$ conductivity of the layer $1,2,3$

Zone and the dispersion model of groundwater in coastal areas or areas of a coral island that is in direct contact with sea water surrounding them (Kodoatie, 2012, Fig. 3).

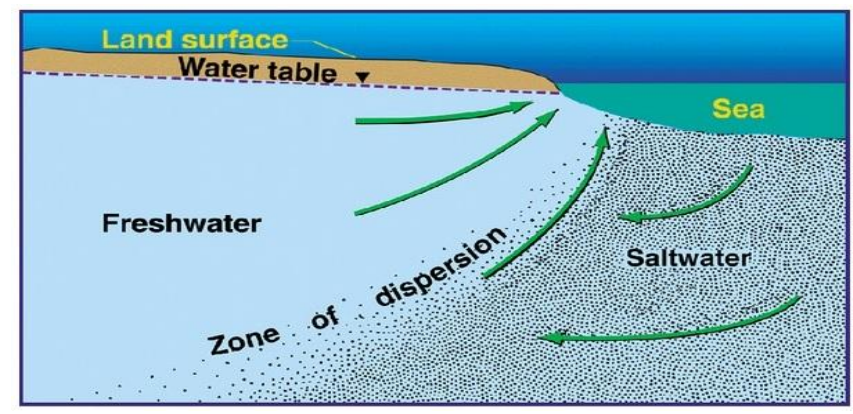

Figure 3: Groundwater dispersion zone at the boundary between salt and freshwater in coastal or area of the island that is heavily influenced by the seawater surrounding them

(Kodoatie, 2012)

\section{Methodology}

\subsection{Research Method}

There are 3 parts of the research methods such as the measurement of field data, secondary data analysis and laboratory data analysis.

- Field data : geological mapping, geoelectric measurements, measurements of water conductivity value of dug wells and test wells, measurement of tide that carried out during the rainy season, the transition season and dry season.

- Secondary data : regional geology data, demographic data, regional tides data, daily and monthly rainfalls.

- Laboratory analyzes: Interpretation of geoelectric crosssection, the analysis of groundwater quality, groundwater dispersion modeling from of the value conductivity and potential unconfined groundwater during the rainy season, the transition season and the dry season.

Research carried out by measurements of field data, secondary data approach and laboratory analysis. The field data includes measurements of fluctuations in groundwater levels at 20 wells dug and 15 wells test every 1 hour on 5 days each the rainy season, the transition season and the dry season. Measurement of tidal fluctuations of 20 days during the rainy season, the transition season and the dry season. The analysis of daily rainfall for one year at the time of the measurement of groundwater level fluctuations and tidal. Data analysis laboratory groundwater samples taken from wells dug and test to determine the quality of groundwater. Based on the analysis of changes in groundwater levels correlated with the conditions and the intensity of the rainfall and tidal fluctuations in the island Satando, then using Software GMS obtained dispersion modeling of groundwater and its potential in the rainy season, the transition season and the dry season on a layer of sand on coral island.

\subsection{Research Location}

Research Location in Satando Island, Village of Mattiro Baji, District of North Liukang Tupabbiring, Pangkep Regency, South Sulawesi Province, Indonesia Country (Fig.1). The study was conducted from January 2014 until December 2014 by observing the condition of groundwater level changes and water quality at 20 dug wells on island residents and 15 test wells on the island Satando.

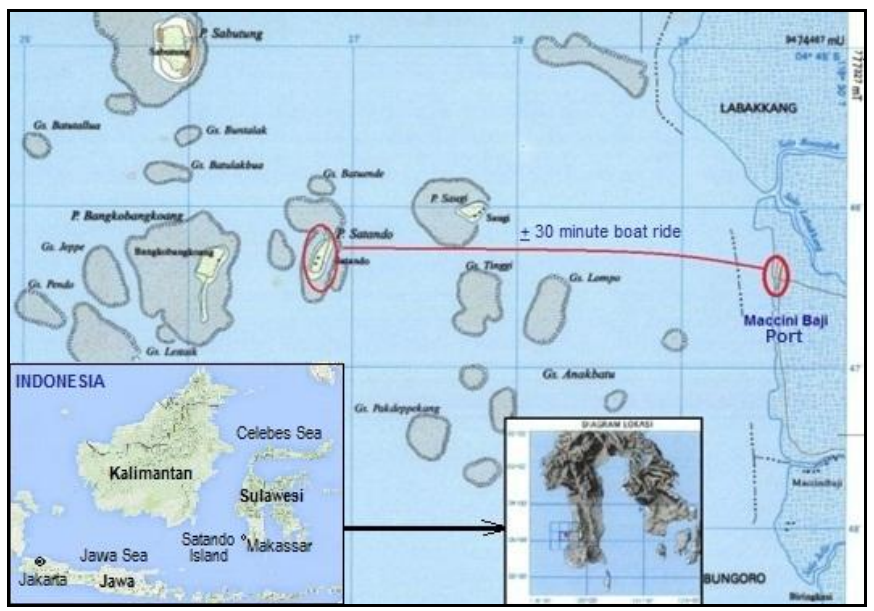

Figure 4: Research location is Satondo Island, Indonesia

\section{Analysis and Discussion}

\subsection{Geological Conditions Coral Island}

Satando Island is a coral island with the condition of the coastal plain is still active and is composed of alluvial coast relatively elongated north northeastern - south southwest, elevation of between 0.0 to 2.3 meters above sea level with an area island is $40.837,48$ metre $^{2}$.

Rock constituent Satando Island that appears on the surface of the alluvial sand beaches sized fine sand - very coarse sand (Fig.2). The results of geoelectric interpretation and description of the soil layer on the test wells showing the arrangement of rock layers in the central part of the island consists of overburden $(0-0,5) \mathrm{m}$, a layer of fine sand-coarse $(0,5$ to 4,5$) \mathrm{m}$, a layer of limestone reef $(4,5$ to 12$) \mathrm{m}$ and a layer of limestone $(12$ to 78,8$) \mathrm{m}$ were regionally composed of Tonasa limestones formation and alluvial deposits. 


\section{International Journal of Science and Research (IJSR) \\ ISSN (Online): 2319-7064}

Index Copernicus Value (2013): 6.14 | Impact Factor (2014): 5.611
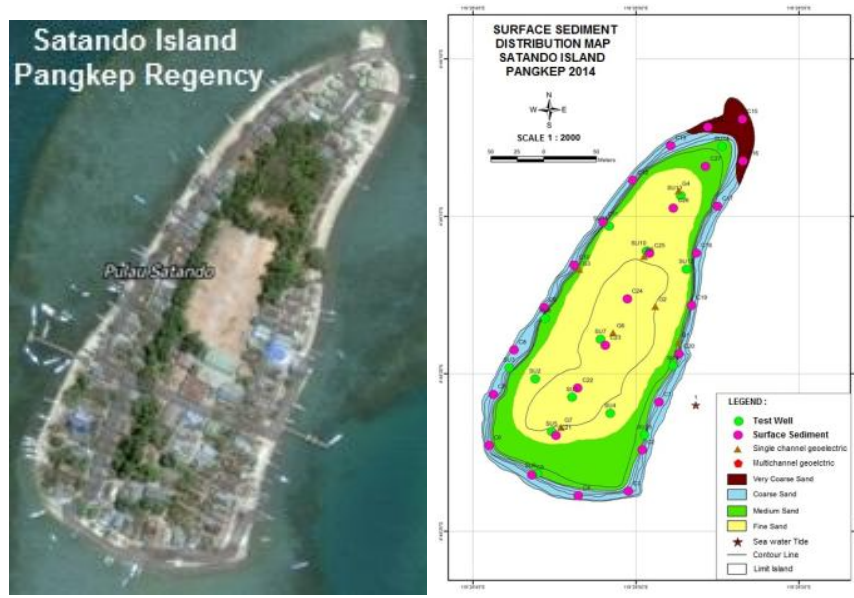

Figure 5: Satondo Island and sand sediment distribution

\subsection{Geoelectrical Analysis}

Geoelectrical measurements in locations Satando Island Region is using equipment geoelectrical resistivity Naniura type NRD $300 \mathrm{HF}$ for methods singgle channel and S-Field 32 channel to multi-channel. Location geoelectric measuring point, length and direction of stretch as shown in Table 4. Geoelectrical single channel is 7 line and geoelectrical multichannel is 3 line with a penetration depth of 27.1 meters to 78.8 meters and resisitivity value range is between 0.00659 to $875 \Omega$ meter.

Table 4: Position coordinates, length and direction of stretch of the geoelectric measurement Satando Island.

\begin{tabular}{|c|c|c|c|c|c|}
\hline \multirow{2}{*}{$\begin{array}{c}\text { Geo- } \\
\text { electric }\end{array}$} & \multicolumn{2}{|c|}{ Coordinate } & \multicolumn{3}{|c|}{ Line Geoeletrical } \\
\hline & Latitude & Longitude & Long & Direction & Method \\
\hline GL.1 & $04^{\circ} 46^{\prime} 19,00^{\prime \prime}$ & $119^{\circ} 26^{\prime} 51,31^{\prime \prime}$ & $400 \mathrm{M}$ & $\mathrm{N} 205^{\circ} \mathrm{E}$ & Single \\
\hline GL.2 & $04^{\circ} 46^{\prime} 17,86^{\prime \prime}$ & $119^{\circ} 26^{\prime} 50,59^{\prime \prime}$ & $400 \mathrm{M}$ & $\mathrm{N} 205^{\circ} \mathrm{E}$ & Single \\
\hline GL.3 & $04^{\circ} 46^{\prime} 16,68^{\prime \prime}$ & $119^{\circ} 26^{\prime} 48,25^{\prime \prime}$ & $400 \mathrm{M}$ & $\mathrm{N} 205^{\circ} \mathrm{E}$ & Single \\
\hline GL.4 & $04^{\circ} 46^{\prime} 15,80^{\prime \prime}$ & $119^{\circ} 26^{\circ} 48,20^{\prime \prime}$ & $100 \mathrm{M}$ & $\mathrm{N} 310^{\circ} \mathrm{E}$ & Single \\
\hline GL.5 & $04^{\circ} 46^{\prime} 16,30^{\prime \prime}$ & $119^{\circ} 26^{\prime} 50,25^{\prime \prime}$ & $120 \mathrm{M}$ & $\mathrm{N} 315^{\circ} \mathrm{E}$ & Single \\
\hline GL.6 & $04^{\circ} 46^{\prime} 18,70^{\prime \prime}$ & $119^{\circ} 26^{\prime} 49,28^{\prime \prime}$ & $150 \mathrm{M}$ & $\mathrm{N} 290^{\circ} \mathrm{E}$ & Single \\
\hline GL. 7 & $04^{\circ} 46^{\prime} 20,30^{\prime \prime}$ & $119^{\circ} 26^{\prime} 48,10^{\prime \prime}$ & $150 \mathrm{M}$ & $\mathrm{N} 312^{\circ} \mathrm{E}$ & Single \\
\hline M.1 & $04^{\circ} 46^{\prime} 20,76^{\prime \prime}$ & $119^{\circ} 26^{\prime} 48,09^{\prime \prime}$ & $150 \mathrm{M}$ & $\mathrm{N} 295^{\circ} \mathrm{E}$ & Mullti \\
\hline M.2 & $04^{\circ} 46^{\prime} 18,85^{\prime \prime}$ & $119^{\circ} 26^{\prime} 49,01^{\prime \prime}$ & $400 \mathrm{M}$ & $\mathrm{N} 210^{\circ} \mathrm{E}$ & Multi \\
\hline M.3 & $04^{\circ} 46^{\prime} 16,06^{\prime \prime}$ & $119^{\circ} 26^{\prime} 50,45^{\prime \prime}$ & $110 \mathrm{M}$ & $\mathrm{N} 320^{\circ} \mathrm{E}$ & Multi \\
\hline
\end{tabular}

Interpretation of geoelectrical cross-section resulted in the composition of soil and rock layers vertically in the central part of the island consists of overburden $(0-0,5 \mathrm{~m})$, fine sand - coarse $(0,5$ to $3,5 \mathrm{~m})$, limestone reefs $(3,5-12 \mathrm{~m})$, fractured limestones $(12-39 \mathrm{~m})$, limestone $(39-57 \mathrm{~m})$ and a solid limestone (57 to $78,8 \mathrm{~m}$ ), figure 5 .

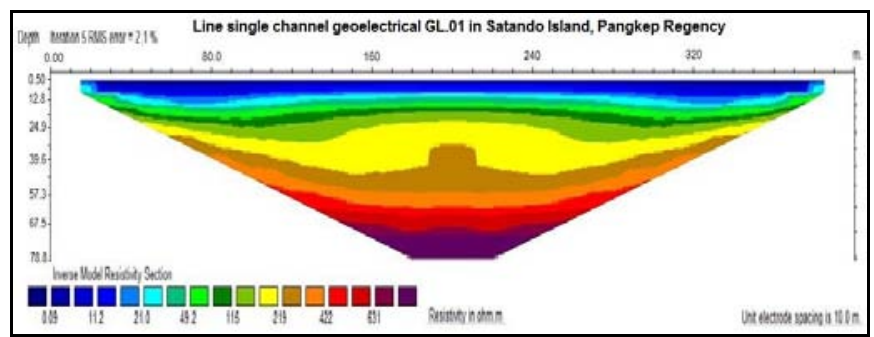

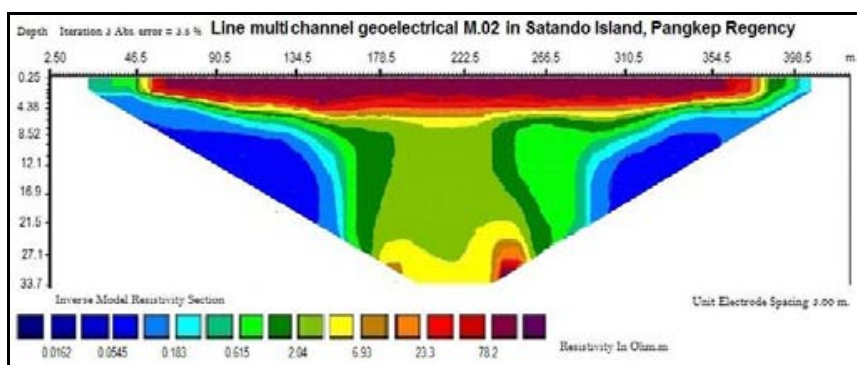

Figure 5: Resistivity cross-section single and multi channel at Coral Island area Satando, Pangkep Regency.

\subsection{Test Wells and Dug Wells in Coral Island}

Data from 20 Dug wells and 15 test wells in the area of the coral island on Santando shows the condition of the water produced varied in terms of quantity, quality, potency and ability to produce fresh water conditions, the rainy season, the transition season and the dry season, Fig. 6 and Fig.7.

\begin{tabular}{|c|c|c|c|c|c|}
\hline \multirow{2}{*}{$\begin{array}{c}\text { Test } \\
\text { Wells }\end{array}$} & \multicolumn{2}{|c|}{ Test Wells Coordinate } & \multicolumn{3}{c|}{ Test Wells Condition } \\
\cline { 2 - 6 } & Lintang & Bujur & Depth SU 1 & Depth SU 2 & Height \\
\hline SU.1 & $04^{\circ} 46^{\prime} 20,75^{\prime \prime}$ & $119^{\circ} 26^{\prime} 47,9^{\prime \prime}$ & $4,75 \mathrm{M}$ & $2,00 \mathrm{M}$ & $2,27 \mathrm{M}$ \\
\hline SU.2 & $04^{\circ} 46^{\prime} 20,16^{\prime \prime}$ & $119^{\circ} 26^{\prime} 48,0^{\prime \prime}$ & $4,70 \mathrm{M}$ & $1,75 \mathrm{M}$ & $2,16 \mathrm{M}$ \\
\hline SU.3 & $04^{\circ} 46^{\prime} 19,81^{\prime \prime}$ & $119^{\circ} 26^{\prime} 47,6^{\prime \prime}$ & $4,80 \mathrm{M}$ & - & $1,98 \mathrm{M}$ \\
\hline SU.4 & $04^{\circ} 46^{\prime} 21,5^{\prime \prime}$ & $119^{\circ} 26^{\prime} 47,2^{\prime \prime}$ & $4,70 \mathrm{M}$ & $2,00 \mathrm{M}$ & $2,14 \mathrm{M}$ \\
\hline SU.5 & $04^{\circ} 46^{\prime} 21,83^{\prime \prime}$ & $119^{\circ} 26^{\prime} 48,3^{\prime \prime}$ & $4,75 \mathrm{M}$ & $2,00 \mathrm{M}$ & $2,15 \mathrm{M}$ \\
\hline SU.6 & $04^{\circ} 46^{\prime} 23,15^{\prime \prime}$ & $119^{\circ} 26^{\prime} 48,6^{\prime \prime}$ & $5,10 \mathrm{M}$ & - & $1,95 \mathrm{M}$ \\
\hline SU.7 & $04^{\circ} 46^{\prime} 18,90^{\prime \prime}$ & $119^{\circ} 26^{\prime} 48,5^{\prime \prime}$ & $5,00 \mathrm{M}$ & $1,80 \mathrm{M}$ & $2,25 \mathrm{M}$ \\
\hline SU.8 & $04^{\circ} 46^{\prime} 18,24^{\prime \prime}$ & $119^{\circ} 26^{\prime} 47,9^{\prime \prime}$ & $4,90 \mathrm{M}$ & $1,50 \mathrm{M}$ & $2,02 \mathrm{M}$ \\
\hline SU.9 & $04^{\circ} 46^{\prime} 19,74^{\prime \prime}$ & $119^{\circ} 26^{\prime} 48,5^{\prime \prime}$ & $4,90 \mathrm{M}$ & - & $1,98 \mathrm{M}$ \\
\hline SU.10 & $04^{\circ} 46^{\prime} 16,09^{\prime \prime}$ & $119^{\circ} 26^{\prime} 48,3^{\prime \prime}$ & $4,80 \mathrm{M}$ & $1,80 \mathrm{M}$ & $2,20 \mathrm{M}$ \\
\hline SU.11 & $04^{\circ} 46^{\prime} 15,31^{\prime \prime}$ & $119^{\circ} 26^{\prime} 48,4^{\prime \prime}$ & $5,00 \mathrm{M}$ & $1,50 \mathrm{M}$ & $2,08 \mathrm{M}$ \\
\hline SU.12 & $04^{\circ} 46^{\prime} 16,67^{\prime \prime}$ & $119^{\circ} 26^{\prime} 48,6^{\prime \prime}$ & $5,00 \mathrm{M}$ & $1,50 \mathrm{M}$ & $2,05 \mathrm{M}$ \\
\hline SU.13 & $04^{\circ} 46^{\prime} 14,34^{\prime \prime}$ & $119^{\circ} 26^{\prime} 48,5^{\prime \prime}$ & $5,10 \mathrm{M}$ & $1,75 \mathrm{M}$ & $2,14 \mathrm{M}$ \\
\hline SU.14 & $04^{\circ} 46^{\prime} 12,78^{\prime \prime}$ & $119^{\circ} 26^{\prime} 48,6^{\prime \prime}$ & $5,00 \mathrm{M}$ & - & $1,95 \mathrm{M}$ \\
\hline SU.15 & $04^{\circ} 46^{\prime} 21,94^{\prime \prime}$ & $119^{\circ} 26^{\prime} 49,2^{\prime \prime}$ & $5,35 \mathrm{M}$ & - & $1,92 \mathrm{M}$ \\
\hline
\end{tabular}

Figure 6: Coordinates, height and depth of test wells

\begin{tabular}{|c|c|c|c|c|c|}
\hline \multirow{2}{*}{ No Noll } & \multicolumn{2}{|c|}{ Coordinate dug wells } & \multicolumn{3}{|c|}{ Condition dug wells } \\
\hline & Latitude & Longitude & Depth & diametre & height \\
\hline S.1 & $04^{\circ} 46^{\prime \prime} 20,8^{\prime}$ & $119^{\circ} 26^{\prime} 47,9^{*}$ & $1,72 \mathrm{M}$ & $0,90 \mathrm{M}$ & $2,29 \mathrm{M}$ \\
\hline 5.2 & $04^{\circ} 46^{\prime} 20,5^{\prime}$ & $119^{\circ} 26^{\prime \prime} 48,0^{\prime \prime}$ & $1.67 \mathrm{M}$ & $0,75 \mathrm{M}$ & $2,28 \mathrm{M}$ \\
\hline 5.3 & $04^{\circ} 46^{\prime} 20,5^{*}$ & $119^{\circ} 26^{\prime} 47.6^{*}$ & $1,63 \mathrm{M}$ & $0.90 \mathrm{M}$ & $2,26 \mathrm{M}$ \\
\hline S.4 & $04^{\circ} 46^{\prime} 21,6^{\prime \prime}$ & $119^{\circ} 26^{\prime} 47,2^{\prime \prime}$ & $2,55 \mathrm{M}$ & $0,70 \mathrm{M}$ & $2,25 \mathrm{M}$ \\
\hline 5.5 & $04^{*} 46^{\prime \prime} 21,2^{\prime \prime}$ & $119^{\circ} 26^{*} 48,3^{*}$ & $1,62 \mathrm{M}$ & $0,85 \mathrm{M}$ & $2,23 \mathrm{M}$ \\
\hline 5.6 & $04^{*} 46^{\prime 2} 20,4^{*}$ & $119^{=} 26^{x} 48,6^{*}$ & $1,57 \mathrm{M}$ & $0,80 \mathrm{M}$ & $2,26 \mathrm{M}$ \\
\hline 5.7 & $04^{\circ} 46^{\prime \prime} 19,7^{\prime \prime}$ & $119^{=}=26^{\prime \prime} 48,5^{\prime}$ & $1,55 \mathrm{M}$ & $0,80 \mathrm{M}$ & $2,25 \mathrm{M}$ \\
\hline S.8 & $0.4^{\circ} 46^{\prime} 20,1^{*}$ & $119^{\circ} 26^{\prime} 47,9^{*}$ & $1,58 \mathrm{M}$ & $0,80 \mathrm{M}$ & $2,26 \mathrm{M}$ \\
\hline 5.9 & $04^{\circ} 46^{\prime} 19,4^{\prime \prime}$ & $119^{\circ} 26^{\prime} 48,5^{\prime \prime}$ & $1,70 \mathrm{M}$ & $0,85 \mathrm{M}$ & $2,26 \mathrm{M}$ \\
\hline 5.10 & $04^{\circ} 46^{\prime} 19,2^{\prime \prime}$ & $119^{\circ} 26^{\prime} 48,3^{\prime \prime}$ & $1,70 \mathrm{M}$ & $0,85 \mathrm{M}$ & $2,25 \mathrm{M}$ \\
\hline 5.11 & $04^{\circ} 46^{\prime} 19,0^{\prime \prime}$ & $119^{\circ} 26^{\prime} 48,4^{\prime \prime}$ & $1,70 \mathrm{~m}$ & $0,85 \mathrm{M}$ & $2,25 \mathrm{M}$ \\
\hline S.12 & $04^{\circ} 46^{\prime} 18,9^{\prime \prime}$ & $119^{\circ} 26^{\prime} 48,6^{\prime \prime}$ & $1,70 \mathrm{M}$ & $0,85 \mathrm{M}$ & $2,26 \mathrm{M}$ \\
\hline 5.13 & $04^{\circ} 46^{\prime} 18,5^{*}$ & $119^{\circ} 26^{\prime} 48,5^{-}$ & $1,63 \mathrm{M}$ & $0,90 \mathrm{M}$ & $2,25 \mathrm{M}$ \\
\hline S.14 & $04^{\circ} 46^{\prime \prime} 17,5^{\prime}$ & $119^{*} 26^{*} 48,6^{*}$ & $1,65 \mathrm{M}$ & $0,90 \mathrm{M}$ & $2,21 \mathrm{M}$ \\
\hline S.15 & $04^{\circ} 46^{\prime \prime} 16,5^{\prime \prime}$ & $119^{\circ} 26^{\prime} 49,2^{\prime}$ & $1,66 \mathrm{M}$ & $0,85 \mathrm{M}$ & $2,18 \mathrm{M}$ \\
\hline S.16 & $04^{\circ} 46^{\prime} 15,7^{*}$ & $119^{\circ} 26^{\prime} 49,9^{*}$ & $1,65 \mathrm{M}$ & $0,70 \mathrm{M}$ & $2,17 \mathrm{M}$ \\
\hline 5.17 & $04^{\circ} 46^{\prime \prime} 13,8^{\prime \prime}$ & $119^{\circ} 26^{\prime} 51,2^{\prime \prime}$ & $1,66 \mathrm{M}$ & $0,90 \mathrm{M}$ & $2,15 \mathrm{M}$ \\
\hline s.18 & $04^{\circ} 46^{\prime} 17,5^{\prime \prime}$ & $119^{\circ} 26^{*} 51,0^{*}$ & $1,58 \mathrm{M}$ & $0,70 \mathrm{M}$ & $2,20 \mathrm{M}$ \\
\hline S.19 & $04^{\circ} 46^{\prime} 17,8^{*}$ & $119^{\circ} 26^{\prime} 50,7^{\prime}$ & $1,60 \mathrm{M}$ & $0,70 \mathrm{M}$ & $2,21 \mathrm{M}$ \\
\hline 5.20 & $04^{\circ} 46^{\prime} 18,9^{*}$ & $119^{\circ} 26^{\prime} 50.7^{*}$ & $1,58 \mathrm{M}$ & $0.90 \mathrm{M}$ & $2,19 \mathrm{M}$ \\
\hline
\end{tabular}

Figure 7: Coordinates, depth and height of dug wells

\subsection{Groundwater Conductivity Analysis}

Conductivity value unconfined groundwater in 15 test wells and 20 dug wells with a measurement interval every one hour for 5 days (January 14 to 18, 2014) stock fluctuation value changes the conductivity of groundwater in the rainy season is Figure 6 and shows the distribution of horizontal ground water quality as Figure 8 . Fluctuation value changes the conductivity of groundwater in the transition season is

\section{Volume 5 Issue 7, July 2016 www.ijsr.net}




\section{International Journal of Science and Research (IJSR) \\ ISSN (Online): 2319-7064 \\ Index Copernicus Value (2013): 6.14 | Impact Factor (2014): 5.611}

figure 7 and shows the distribution of horizontal ground water quality as figure 9 .

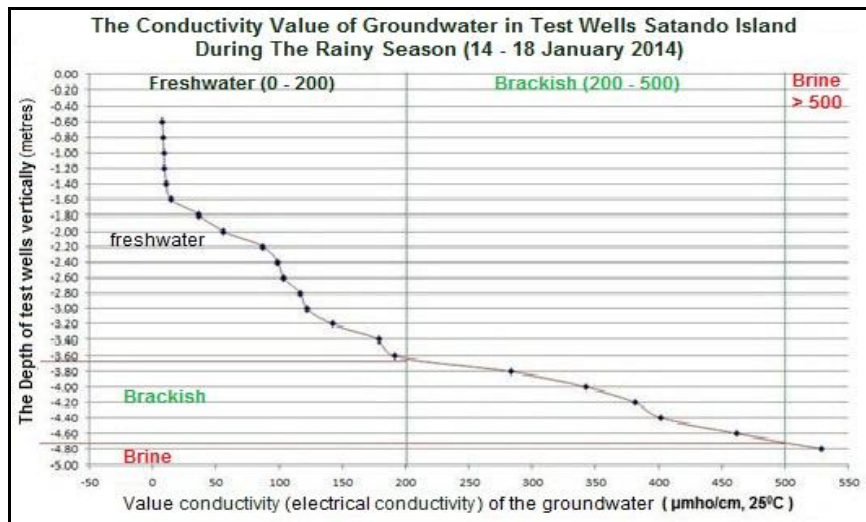

Figure 6: The average value of conductivity of groundwater in test wells on the island Satando during the rainy season, 2014.

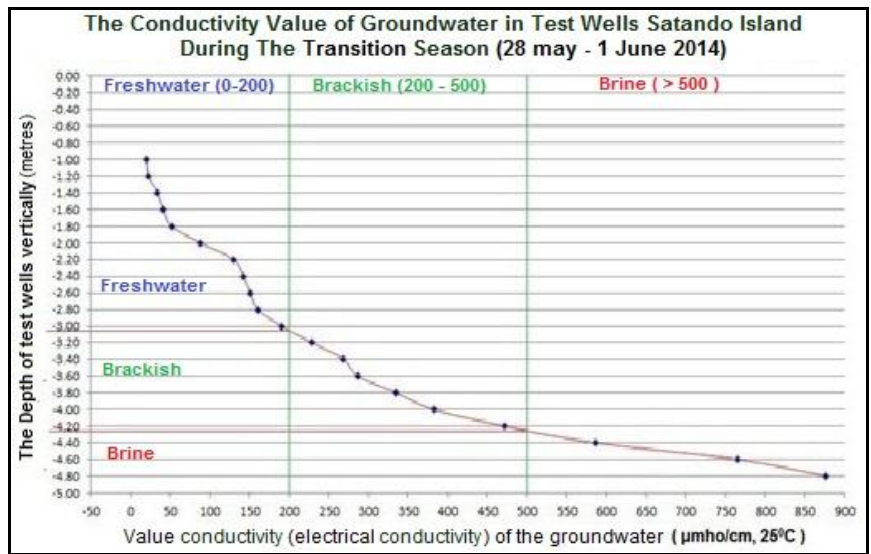

Figure 7: The average value of conductivity of groundwater in test wells on the island Satando during the transition season, 2014

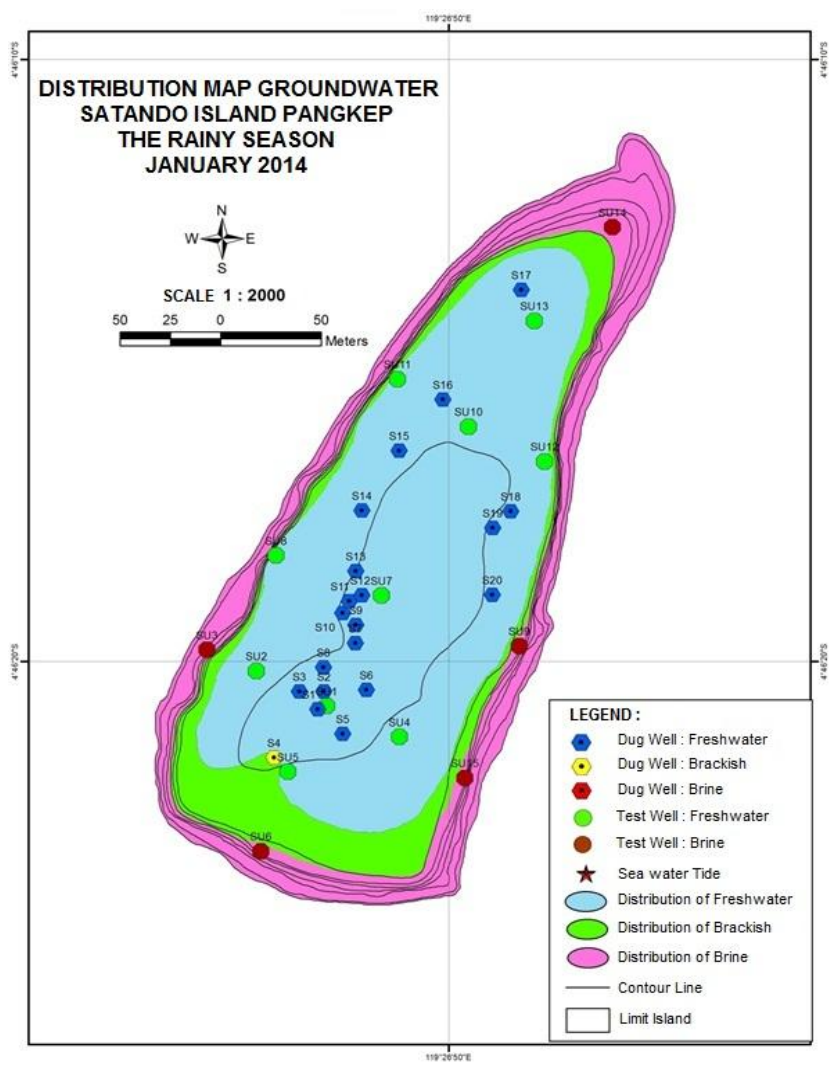

Figure 8: Distribution of groundwater potential horizontally on the coral island during the rainy season in 2014

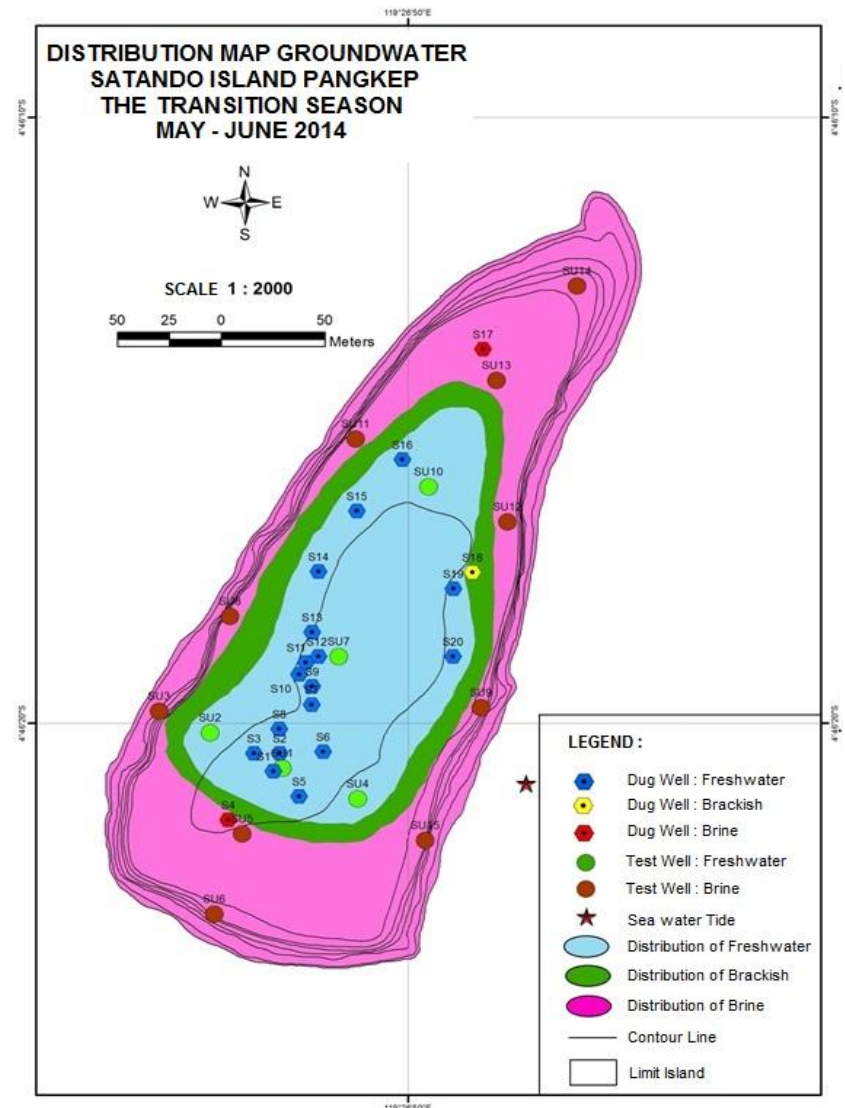

Figure 9: Distribution of groundwater potential horizontally on the coral island during the transition season in 2014

Fluctuation value changes the conductivity of groundwater in the dry season is figure 10 and shows the distribution of horizontal ground water quality as figure 11 .

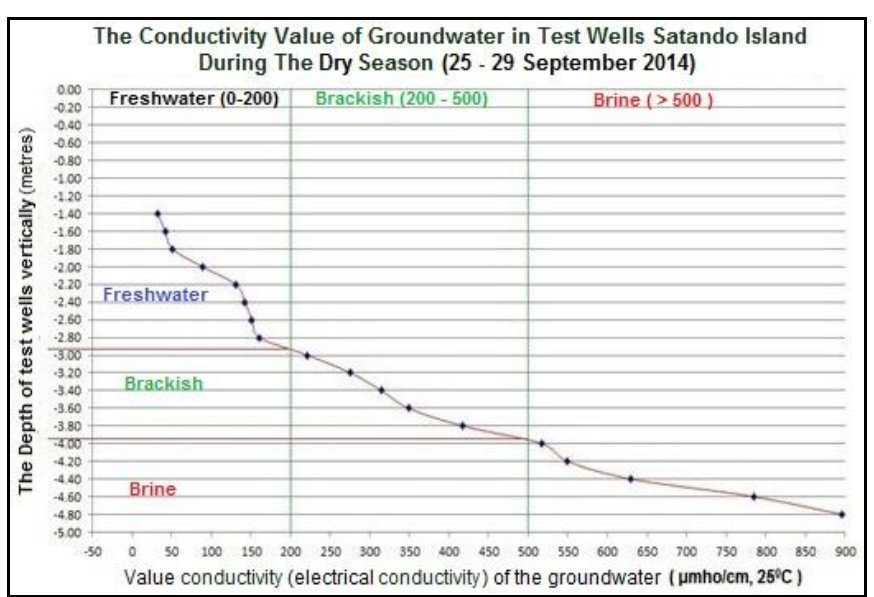

Figure 10: The average value of conductivity of groundwater in test wells on the island Satando during the dry season, 2014

\section{Volume 5 Issue 7, July 2016 www.ijsr.net}




\section{International Journal of Science and Research (IJSR) \\ ISSN (Online): 2319-7064}

Index Copernicus Value (2013): 6.14 | Impact Factor (2014): 5.611

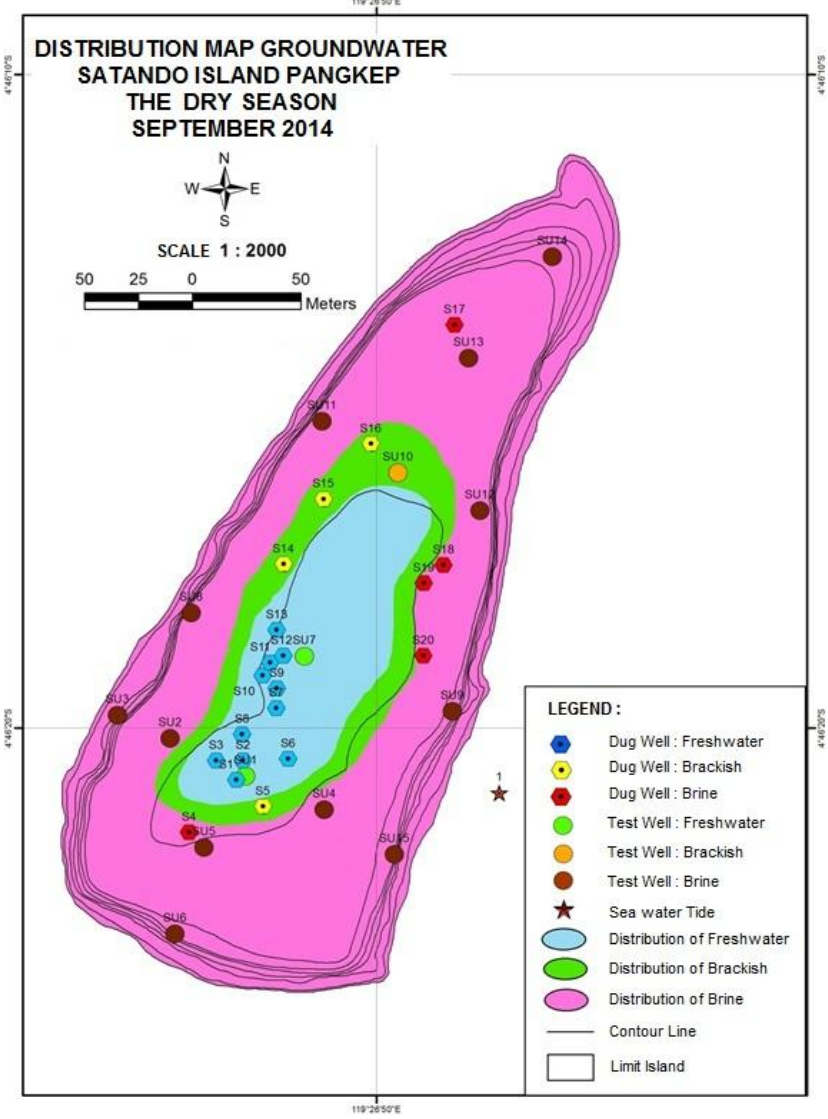

Figure 11: Distribution of groundwater potential horizontally on the coral island during the dry season in 2014

\subsection{Unconfined Groundwater Dispersion Model}

Freshwater needs Satando Island residents 32,22 metre $^{3} /$ day. Unconfined groundwater dispersion model coral island in the rainy season to produce a layer thickness of fresh water in the central part of the island is 2,74 metres $(-1.33 \mathrm{~m}$ below sea level), which produces the potential for fresh water in the sand layer is $10588,2 \mathrm{~m}^{3}$, which can be used only 2117,62 $\mathrm{m}^{3}$ are able to meet the needs of fresh water island residents. As the season transitions freshwater layer thickness in the central part of the island is 2,10 metres $(-0.93 \mathrm{~m}$ below sea level), which produces the potential for fresh water in the sand layer is $4688,9 \mathrm{~m}^{3}$, which can be used only $937,78 \mathrm{~m}^{3}$ are still able to meet the fresh water of the island residents but have had to wait $2-3$ hours to get fresh water. During the dry season the thickness of the layer of fresh water in the central part of the island is 1,54 metres $(-0,53 \mathrm{~m}$ below sea level), which produces the potential for fresh water in the sand layer is $1375,9 \mathrm{~m}^{3}$, which can be used only $275,18 \mathrm{~m}^{3}$ ( water that is above a depth of 1,75 m), supply of fresh water on the island is not able to meet all the needs of the residents of the island, so that should bring fresh water from the mainland to meet the needs of fresh water.

Unconfined groundwater dispersion models coral island in the area Satando in the rainy season, the transition season and the dry season as in figure 12

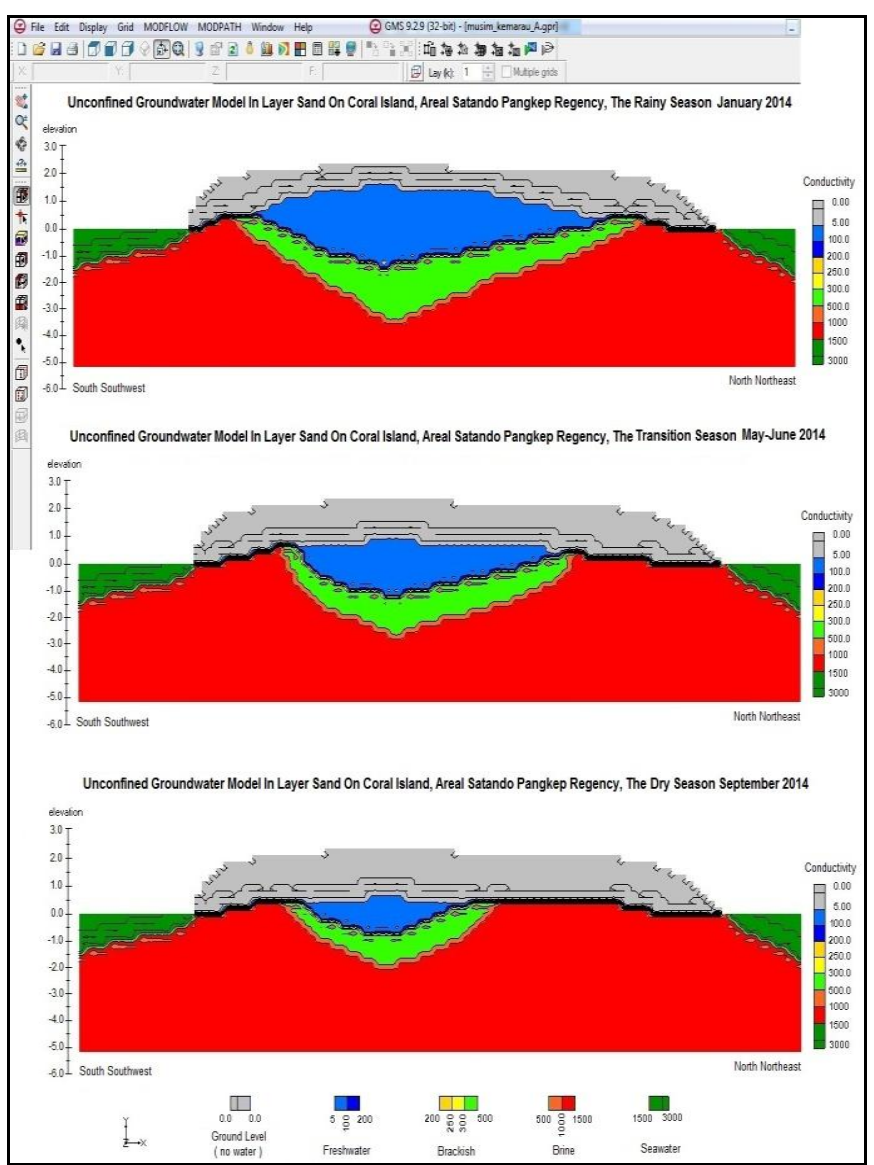

Figure 12: Unconfined groundwater dispersion models coral island in the area Satando in 2014

\section{Conclusion}

Geological mapping indicates Satando Island area is a coastal plain that is still active with the type of alluvial coast and the elevation of 0,0 to 2,3 meters.

Interpretation of geoelectrical cross-section resulted in the composition of soil and rock layers vertically in the central part of the island consists of overburden $(0-0,5 \mathrm{~m})$, fine sand - coarse $(0,5-3,5 \mathrm{~m})$, limestone reefs $(3,5-12 \mathrm{~m})$, fractured limestones $(12-39 \mathrm{~m})$, limestone $(39-57 \mathrm{~m})$ and a solid limestone $(57-78.8 \mathrm{~m})$.

Dispersion model unconfined groundwater coral island in the rainy season to produce a layer thickness of fresh water in the central part of the island is $2.74 \mathrm{~m}$ which produces the potential for fresh water is $10588.2 \mathrm{~m} 3$, which can be used only $2117.62 \mathrm{~m} 3$ are able to meet the needs of fresh water island residents.

Dispersion model unconfined groundwater coral island in the dry season to produce a layer thickness of fresh water in the central part of the island is $1.54 \mathrm{~m}$ which produces the potential for fresh water is $1375.9 \mathrm{~m} 3$, which can be used only $275.18 \mathrm{~m} 3$, supply of fresh water on the island is not able to meet all the needs of the residents of the island, so that should bring fresh water from the mainland to meet the needs of fresh water. 


\section{References}

[1] Adang S and Sri M. Yuningsih, 2009, Determination of Geoelectrical Groundwater Exploration in Point Kemie, East Flores, Irrigation Journal (Vol.4 No.1, June 2009).

[2] Arenas D and Simler. L., 1991, Hydrology and Water Resources of Small Islands: A Practical Guide, Studies and Report on Hydrology No. 49 UNESCO.

[3] Benfetta H., 2009, Study of the Fluctuations of Subsoil Waters the Plain of Ghriss Mascara-Algeria, European Journal of Scientific Research, 1450-216X Vol.34 No.2

[4] Boggs, J.R.S., 1995, Principles of Sedimentology and Stratigraphy, 2 edition, Prentice-Hall, Inc.A. Simon and Schuster Company, Upper Saddle River, New Yersey.

[5] Cindhy A., Adhytia L., Rima R., Riandy, 2012, Model of Groundwater Flow, Journal of Soil and Groundwater Pollution, Civil and Environmental Engineering, UI.

[6] Cole Parmer, 2006, Conductivity Theory and Technical Tips, coleparmer. com / TechLibrary Article / 78, 2006.

[7] Das, Braja M., 1995, Soil Mechanics, 1 and 2, Erlangga publisher, Surabaya, Indonesia.

[8] Fatimah and Sobriyah 2006, Water Conservation In Small Islands, Proceedings Hathi XXXIII in Manado, ISBN 978-979-15616-4-8.

[9] Hardiyatmo, H.C. 2010, Soil Mechanics 1, Gajah Mada University Press, Yogyakarta, Indonesia.

[10] Katsifarakis, K.L., 2009, Optimization of Grounwater Resources Management In Polluted Aquifers, Global NEST Journal, Volume 11, Nomor 3, pp 283-290.

[11] Khodapanah, L., 2009, Groundwater Quality Assessment for Different Purposes in Eshtehard District, Tehran, Iran, European Journal of Scientific Research ISSN 1450-216X Vol.36 No.4

[12] Kodoatie, R.J., 2012, Spatial Groundwater, Publisher Andi, Yogyakarta, Indonesia.

[13] Neyamadpour, A, Samsudin, T, Abdullah, W., 2009, An Application of three-Dimensional electrical resistivity imaging for the detection of undergrouand wastewater system, Geophys (53): 389-402.

[14] Pettijohn F. J., 1975, Sedimentary Rock, third edition, Harper \& Row, Publishers, New York.

[15] Priscilla, A., 2008, Evaluation of ground water quality of Mubi town in Adamawa State, Nigeria, African Journal of biotechnology Vol. 7 (11), pp. 1712-1715.

[16] Rolia, Eva, 2011, Geoelectrical Method for Detecting Groundwater, Tapak Journal Vol.01, No. 01, 2011.

[17] Telford, W.M, Geldart, L and Sheriff, R., 1990, Applied Geophysics, 2Edition, Cambridge Univ. Press, US A

[18] Yudianto, 2006, the management model of groundwater in the basin aquifer Pasuruan for continuity availability of renewable, Hathi Proceedings of XXXIII in Manado.

[19] Zbigniew, C. and Luciano, T., 2011, The construction of Ito model for geoelectrical signals, Journal Physica A 